\title{
Analisis Komentar Followers terhadap Identitas Gender Beauty Influencer Laki-Laki di Instagram
}

\author{
Valent Novitaria, Farid Rusdi \\ valent.915170143@stu.untar.ac.id,farid@fikom.untar.ac.id \\ Fakultas Ilmu Komunikasi Universitas Tarumanagara
}

\begin{abstract}
A phenomenon that starts to become popular in social media, especially Instagram, is becoming a content creator that focuses on beauty, also known as beauty influencer. Beauty influencers are identical to pretty and feminine concepts, but as the time goes by, male beauty influencers started to emerge as well. This created positive and negative opinions in society, especially about their gender identities. In Indonesia, genderless issue starts to attract public attention. Many people started to question the stiff gender categories by expressing their opinions regarding this phenomenon. This research was conducted with qualitative approach with Teun Van Dijk text analysis method. Data collection was conducted by observations, interviews, and documentations. Based on analysis, it is found that changes in society may affect an individual's social system, attitude, value, and behavioural pattern. People in the past recognise that men are masculine and women are feminine. Nowadays, gender limitation line is getting thinner, prioritising human rights. This proves that the perception of gender identities in the society are slowly changing.
\end{abstract}

Keywords: beauty influencer, discourse analysis, followers, gender identity, instagram

\begin{abstract}
Abstrak
Salah satu fenomena yang marak di media sosial khususnya Instagram adalah menjadi content creator di bidang kecantikan atau yang biasa disebut dengan beauty influencer. Beauty influencer identik dengan konsep cantik dan feminine. Seiring perkembangan zaman, saat ini ada pula beauty influencer berjenis kelamin laki-laki. Hal tersebut memunculkan berbagai opini positif maupun negatif dalam masyarakat, khususnya mengenai identitas gender yang mereka tampilkan. Di Indonesia, isu genderless semakin menjadi perhatian publik. Orang-orang mulai mempertanyakan kategori gender yang kaku dan mengemukakan berbagai pendapat atas fenomena ini. Penelitian ini dilakukan dengan pendekatan penelitian kualitatif menggunakan teknik analisis wacana Teun Van Dijk. Metode pengumpulan data dilakukan dengan menggunakan observasi, wawancara, dan dokumentasi. Berdasarkan hasil analisis dapat diketahui bahwa adanya perubahan dalam masyarakat dapat mempengaruhi sistem sosial, sikap, nilai, dan pola perilaku individu. Masyarakat pada zaman dulu memiliki persepsi bahwa pria harus maskulin dan perempuan feminin. Sementara zaman sekarang, garis pembatasan gender semakin tipis dan lebih mengutamakan hak manusia. Hal tersebut membuktikan bahwa persepsi mengenai identitas gender yang ada dalam masyarakat sudah perlahan-lahan berubah.
\end{abstract}

Kata Kunci: analisis wacana, beauty influencer, followers, identitas gender, instagram

\section{Pendahuluan}

Komunikasi antara manusia dapat terjalin mudah dan cepat dengan semakin berkembangnya teknologi yang canggih pada zaman sekarang. Ada berbagai jenis 
platform yang dapat digunakan oleh masyarakat untuk mengekspresikan diri masingmasing, salah satu yang banyak digunakan adalah media sosial. Dalam media sosial siapapun dapat membagikan pesan yang berupa tulisan, foto, maupun video menarik yang dapat dilihat oleh semua orang di dunia.

Berdasarkan data dari We Are Social, di Indonesia terdapat $80 \%$ orang yang menggunakan media sosial Instagram. Artinya, dari 150 juta pengguna media sosial di Indonesia, sekitar 120 juta orang telah menggunakan Instagram. Saat ini, media sosial Instagram seringkali dimanfaatkan oleh banyak pihak terutama content creator, public figure, maupun influencer untuk menggunggah konten-konten menarik atau hasil karya yang ingin dibagikan kepada masyarakat. Media sosial memberikan kemudahan kepada khalayak untuk menampilkan gaya hidup yang dimiliki serta mengeksplor diri.

Fenomena yang marak di media sosial Instagram saat ini adalah menjadi seorang content creator yang bergerak dalam bidang kecantikan atau yang biasa disebut dengan beauty influencer. Kemunculan beauty influencer sangat memberikan pengaruh positif dalam memperkenalkan sebuah produk khususnya produk kecantikan. Mereka menjadi dikenal masyarakat karena sering memberikan pengetahuan dalam dunia kecantikan seperti tutorial maupun review makeup. Banyak sekali beauty influencer terkenal yang mempunyai kemampuan makeup unik dan berasal dari berbagai kalangan maupun latar belakang yang berbeda. Dalam mempertahankan eksistensinya, beauty influencer memiliki cara-cara unik tersendiri untuk membuat konten.

Beauty influencer sangat identik dengan konsep yang cantik dan feminin. Mereka berlomba-lomba untuk menampilkan sisi kecantikan yang dimiliki sehingga dapat menarik perhatian masyarakat yang melihat konten mereka. Dalam dunia beauty influencer saat ini ada pula yang berjenis kelamin laki-laki. Hal ini memunculkan opini yang positif maupun negatif di dalam masyarakat. Seperti yang diketahui, laki-laki biasanya dikenal dengan sisi yang maskulin dan tampan, tetapi yang ditampilkan oleh beauty influencer laki-laki tersebut berbanding terbalik dengan jenis kelaminnya.

Dalam budaya masyarakat Indonesia, gender laki-laki memiliki makna harus maskulin dan perempuan harus feminin. Ilmuwan sosial memperkenalkan istilah gender untuk menjelaskan perbedaan antara laki-laki dan perempuan yang diciptakan Tuhan dan bentuk budaya yang telah dipelajari serta disosialisasikan dari kecil. Gender dapat diartikan sebagai hasil dari bentuk konstruksi sosial dan budaya yang dipelajari melalui proses sosialisasi dari generasi ke generasi, sehingga terdapat perbedaan antara laki-laki dan perempuan dalam peran, tanggung jawab, fungsi, dan status. Gender adalah hasil kesepakatan antara manusia yang tidak bersifat kodrati. (Puspitawati, 2013). Sebab itu, gender dapat berubah dari dari waktu ke waktu dan dari satu tempat ke tempat lain.

Perbedaan sosial dalam konsep gender menimbulkan perbedaan peran perempuan dan laki-laki di dalam lingkungan masyarakat. Perbedaan gender telah melekat dalam perspektif masyarakat, sehingga umumnya sering dianggap sesuatu yang mutlak sebagai ciri biologis yang dimiliki oleh perempuan dan laki-laki. Gender seseorang tidak bersifat kodrati, dapat dipertukarkan serta dapat berubah sesuai budaya yang diterima. Banyak yang berpendapat bahwa identitas gender bersifat permanen, padahal identitas juga memiliki sifat sosial selain digunakan untuk merepresentasikan diri. Artinya, bentuk identitas dapat berubah dan berkaitan 
dengan berbagai latar belakang sosial budaya dan kultural serta maknanya dapat berubah menurut waktu, ruang, dan pemakaian (Rani \& Udasmoro, 2015).

Menurut Barker (2008), identitas dapat dipresentasikan melalui berbagai bentuk yang dapat dikenali oleh diri sendiri dan orang lain. Artinya, identitas merupakan esensi yang dapat dijelaskan dengan sikap, kepercayaan, selera, dan gaya hidup seseorang. Hal tersebut terjadi pada masyarakat sekarang yang merepresentasikan diri melalui berbagai bentuk seperti gaya hidup, sikap, maupun penampilan. Mereka tidak peduli dengan jenis kelamin, melainkan terhadap apa yang membuat mereka senang dan nyaman (Yonatha, 2020). Contohnya pada content creator Instagram laki-laki dalam bidang kecantikan, seperti Alpha Makeup (@andreaslukita_)dan Yudhistira El Vedayadi (@yudhistirawr).

Saat ini dalam ruang lingkup masyarakat Indonesia isu genderless (seseorang yang tidak memiliki gender) semakin menjadi perhatian publik. Banyak sekali orang mulai mempertanyakan kategori gender yang kaku dan mengungkapkan berbagai pendapat mengenai isu tersebut (Farida, 2016). Gender dapat berubah, oleh sebab itu sering ditemui seseorang yang berjenis kelamin laki-laki memiliki perilaku yang feminin dan bergaya seperti perempuan. Demikian juga seseorang yang berjenis kelamin perempuan memiliki tingkah laku dan penampilan seperti laki-laki. Namun, dalam lingkungan masyarakat Indonesia, jika seseorang memiliki identitas yang tidak awam dari yang diketahui masyarakat akan dilihat sebagai individu yang berbeda dari masyarakat lainnya.

Tujuan penelitian ini adalah menganalisis berbagai pendapat atau komentar yang dilontarkan oleh masyakarat khususnya followers dari beauty influencer lakilaki saat melihat konten-konten yang dibagikan identik dengan kecantikan. Komentar yang muncul dalam menghadapi isu ini pasti menuai berbagai pandangan pro maupun kontra.

\section{Metode Penelitian}

Penelitian ini merupakan penelitian kualitatif dengan menggunakan metode analisis. Sugiyono (2013:2) mengemukakan bahwa, metode penelitian pada dasarnya merupakan metode ilmiah untuk memperoleh data dengan maksud dan tujuan tertentu. Jenis metode penelitian yang penulis gunakan dalam penelitian ini adalah dengan menggunakan analisis wacana Teun Van Djik. Analisis wacana digunakan untuk menganalisis wacana-wacana dalam masyarakat, yang meliputi gender, ras, politik, kelas sosial, dan lain-lain.

Data yang digunakan difokuskan pada konstruksi secara kewacanaan, termasuk teks tertulis dalam berbagai bentuk tulisan, atau teks lisan dalam berbagai bentuk tuturan. Wacana tidak hanya dipahami sebagai objek pembelajaran bahasa, tetapi juga digunakan sebagai alat untuk tujuan praktik tertentu. Tujuan yang utama dari analisis wacana adalah membuka keburaman dalam wacana yang membantu untuk menghasilkan hubungan yang tidak seimbang di antara para peserta wacana (Angeline, 2020).

Pada penelitian yang dilakukan oleh penulis, subyek penelitian yang menjadi informan dalam penelitian ini adalah followers beauty influencer laki-laki dan komentar mengenai identitas gender yang ditunjukkan dalam unggahan kontenkonten beauty influencer laki-laki. Sedangkan objek penelitian ini merupakan identitas gender dari beauty influencer laki-laki yaitu Alpha Makeup (@andreaslukita_)dan Yudhistira El Vedayadi (@yudhistirawr). 
Penelitian dilakukan dengan mengumpulkan data melalui: (1) observasi, penulis akan mengamati bagaimana komentar-komentar yang tertulis dalam unggahan akun Instagram beauty influencer laki-laki dan melakukan observasi terhadap opini khalayak. Penulis juga melakukan pengumpulan data melalui media online seperti internet atau jaringan media lain yang menyediakan fasilitas online; (2) Wawancara, dilakukan dengan beberapa followers beauty influencer laki-laki sehingga penulis mendapat gambaran secara langsung mengenai opini-opini khalayak mengenai isu identitas gender dan dan psikolog untuk mendapatkan perspektif yang berbeda dari sisi ahli; dan (3) Dokumentasi, berupa gambar, catatan, transkrip wawancara, dan sebagainya.

Teknik analisis yang digunakan dalam penelitian ini adalah dengan menggunakan metode analisis wacana Teun Van Dijk. Sementara, model analisis data menurut Miles dan Huberman menunjukkan bahwa kegiatan analisis data kualitatif dilakukan dengan interaktif dan berlangsung terus menerus hingga selesai (Sugiyono, 2012:91). Proses analisis terbagi menjadi beberapa bagian, yaitu:

a. Reduksi Data: data yang telah diolah akan memberi gambaran yang lebih rinci, sehingga memudahkan peneliti dalam mengumpulkan data. Reduksi data dilakukan setelah mendapat hasil wawancara dan dokumentasi terkait dengan opini followers beauty influencer laki-laki dalam menanggapi isu identitas gender.

b. Penyajian Data: dilakukan dengan cara memilah data-data, sehingga lebih mudah dipahami saat melakukan penelitian. Proses ini menjadikan data lebih terorganisir dan tersusun dalam sebuah pola hubungan. Data tersebut kemudian diinterpretasi atau dibentuk maknanya menurut metode analisis wacana Teun Van Dijk.

c. Verifikasi Data: Dengan verifikasi data, peneliti dapat mengetahui hasil dari penelitian ini. Hasil yang didapatkan bersifat sementara dan dapat berubah jika ada data yang kurang menyakinkan dalam tahap pengumpulan data.

Teknik keabsahan data dilakukan dengan menggunakan teknik triangulasi. Moleong (2012:330) mengemukakan triangulasi merupakan pemeriksaan keabsahan data yang menggunakan hal-hal lain di luar data tersebut untuk memeriksa atau sebagai perbandingan terhadap data tersebut. Ada empat jenis triangulasi yang digunakan sebagai teknik pemeriksaan yaitu dengan menggunakan sumber, teori, metode, dan penyidik. Dalam penelitian ini, peneliti menggunakan teknik keabsahan data yaitu triangulasi sumber dan triangulasi metode.

Dengan teknik triangulasi dengan sumber, peneliti dapat mengetahui hasil wawancara yang telah dilakukan dari masing-masing sumber atau narasumber penelitian dengan cara membandingkan keaslian informasi yang diperoleh. Peneliti juga menggunakan teknik triangulasi dengan metode, dengan memakai teknik pengumpulan data yang berbeda yaitu observasi, wawancara, dan dokumentasi sehingga kredibiltas data dapat diuji kebenarannya.

\section{Hasil Temuan dan Diskusi}

Dalam penelitian ini, peneliti menggunakan metode penelitian kualitatif dengan teknik analisis wacana yang dikemukakan oleh Teun Van Dijk. Menurutnya, analisis wacana digunakan untuk menganalisis wacana-wacana dalam masyarakat, yang meliputi gender, ras, kelas sosial, politik, dan lain-lain. Analisis wacana digunakan untuk meneliti atau menganalisis bahasa yang akan digunakan secara 
alami, baik berbentuk tertulis maupun lisan, sebagai suatu elemen masyarakat. Data yang digunakan akan difokuskan pada konstruksi secara kewacanaan, termasuk teks tertulis dalam berbagai bentuk tulisan, atau teks lisan dalam berbagai bentuk tuturan.

Teun Van Dijk mengemukakan, analisis wacana terdiri dari lima unsur yaitu: (1) Tindakan, (2) Konteks, (3) Historis, (4) Kekuasaan, dan (5) Ideologi. Pada bagian ini peneliti akan menganalisis komentar-komentar yang dilontarkan masyarakat terutama followers mengenai identitas gender yang diperlihatkan oleh beauty influencer laki-laki dalam media sosial Instagram.

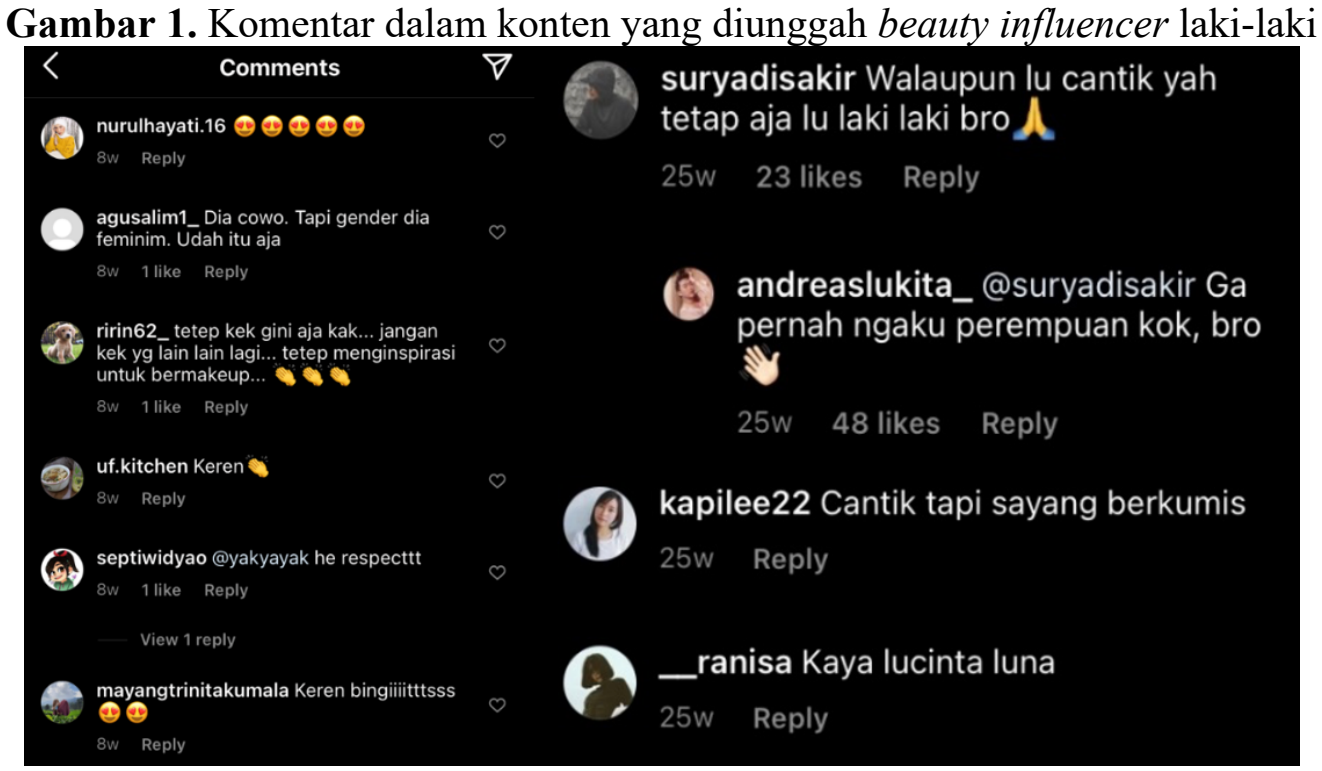

Sumber: Instagram

Pada unsur tindakan, melalui hasil analisis yang telah peneliti lakukan pada kolom komentar dapat dilihat bahwa tindakan dari followers beauty influencer lakilaki sebagian besar adalah mendukungnya untuk dapat tampil maskulin dan juga tampil feminine. Hal ini biasa disebut juga dengan androgini. Androgini merupakan istilah yang digunakan dalam menunjukkan pembagian peran yang setara dalam karakter maskulin dan feminin di saat yang bersamaan.

Followers maupun masyarakat dapat mendukung hal tersebut karena apa yang dilakukan tidak merugikan orang. Selain itu, beauty influencer laki-laki juga menjadi inspirasi banyak orang karena dapat hidup sesuai dengan apa yang ia inginkan. Dalam konten-konten yang diunggah, beauty influencer laki-laki memberikan informasi yang berguna bagi followers-nya, berinteraksi, dan juga mengedukasi followers-nya. Kepribadian yang menyenangkan juga menjadi nilai tambah yang dapat menarik perhatian masyarakat sehingga orang-orang mendukung beauty influencer dengan jenis kelamin laki-laki.

Komentar-komentar negatif dalam unggahan tersebut juga memiliki keterkaitan dengan unsur tindakan. Keterkaitannya adalah bahasa yang dilontarkan dalam unggahan tersebut dapat menggiring opini khalayak untuk berkomentar negatif sama seperti dirinya, yaitu kritikan mengenai identitas gender beauty influencer laki-laki. Pada unsur tindakan, orang tersebut sengaja melontarkan kalimat yang negatif sehingga dapat mempengaruhi orang lain.

Pada unsur konteks, kondisi di zaman sekarang ini yang semakin berkembang menuntut masyarakat untuk menerima perubahan yang ada. Perubahan dalam 
masyarakat dapat mempengaruhi sistem sosial, sikap, nilai, dan pola perilaku individu. Setiap individu pasti mengalami sebuah perubahan dalam hidupnya, baik dalam lingkungan keluarga maupun lingkungan sekitar. Perbedaan tersebut merupakan perubahan sosial yang menekankan perubahan pada aspek kultural atau budaya dan aspek struktural masyarakat. Walaupun seperti yang diketahui budaya bukanlah suatu hal yang bisa berubah dengan mudah dan cepat.

Unsur historis merupakan aspek yang menentukan perkembangan dari wacana. Ditandai dengan era globalisasi yang semakin meluas dan perkembangan internet yang semakin canggih, budaya asing mulai masuk ke Indonesia sehingga menyebabkan pemikiran sebagian besar masyarakat perlahan-lahan menjadi semakin terbuka dan berwawasan luas. Setiap orang berhak dengan bebas menentukan pola pikir dan pandangannya terhadap sesuatu. Masyarakat pada zaman dulu memiliki persepsi bahwa pria harus maskulin dan perempuan feminin. Sementara pada era sekarang, garis pembatasan gender semakin tipis dan emansipasi serta hak-hak manusia lebih diutamakan.

Namun, sebagian kecil masyarakat Indonesia masih ada yang sulit menerima perubahan drastis dalam hal yang mereka yakini, seperti pembatasan gender. Mereka masih menjunjung tinggi nilai-nilai tradisional yang diturunkan secara turun temurun, sehingga munculnya beauty influencer laki-laki di media sosial menjadi hal yang baru bagi follower dan mengganggap hal tersebut adalah hal yang tidak benar. Akibatnya, follower melontarkan kalimat-kalimat negatif yang ditujukan kepada beauty influencer laki-laki karena belum sepenuhnya dapat menerima budaya tersebut.

Melalui komentar yang dilontarkan pada unggahan beauty influencer lakilaki, dapat dilihat hal tersebut merupakan bentuk kekuasaan. Media sosial merupakan salah satu teknologi yang sering dipakai dalam era modern seperti sekarang. Memberikan kemudahan dalam kehidupan sehari-hari, media sosial diciptakan untuk saling terhubung dan berinteraksi hanya melalui gadget. Kemudahan dan kebebasan dalam berekspresi menjadikan media sosial sebagai kebutuhan penting yang harus dimiliki oleh setiap orang.

Kebebasan dalam berekspresi disalurkan melalui media sosial. Seperti halnya masyarakat ataupun follower yang memiliki kekuasaan untuk berkomentar sesuai dengan apa yang ingin ditulisnya. Pengikut ini merasa memiliki hak yang bebas dan tidak terbatas dalam berpendapat, tidak peduli apakah hal tersebut baik atau buruk. Sehingga komentar yang dilontarkan dapat mempengaruhi individu yang menggunggah postingan tersebut. Jika komentar yang diterima positif, individu tersebut akan merasa senang dan terus termotivasi. Sedangkan jika komentar yang diterimanya negatif, hal itu akan mempengaruhi psikologisnya dan menjadikan dirinya terbebani. Pada dasarnya kebebasan yang ada untuk setiap orang memiliki batasan tertentu.

Melalui unsur ideologi, dasar dari perilaku individu atau kelompok menyebabkan timbulnya wacana maupun peristiwa yang membenarkan hal tersebut. Ideologi dapat membentuk nilai, norma dasar, dan prinsip-prinsip yang digerakkan oleh minat dan tujuan. Identitas gender yang ditampilkan dalam unggahan media sosial Instagram beauty influencer laki-laki menyebabkan lahirnya wacana. Beauty influencer laki-laki ingin mengajak dan memberitahukan kepada masyarakat dan followers-nya untuk memiliki pikiran yang lebih terbuka mengenai sebuah identitas gender. Mereka ingin menyampaikan pesan bahwa tidak hanya perempuan yang dapat memiliki sisi feminin dengan memakai makeup atau skincare, tetapi laki-laki 
juga dapat memiliki sisi feminin. Memiliki sisi tersebut tidak dapat mempengaruhi maskulinitas dari laki-laki, beauty influencer laki-laki dapat menggunakan cara tersendiri untuk menunjukkan sisi maskulin.

Persepsi mengenai maskulinitas perlahan-lahan dapat berubah seiring dengan kemajuan zaman dan pola pikir masyarakat yang semakin luas. Hal tersebut akhirnya perlahan-lahan membuka pikiran masyarakat untuk dapat memahami perbedaan, tidak berarti bahwa perbedaan akan menjadikan mereka bukan manusia atau kurang sebagai manusia yang utuh. Identitas gender tidak hanya dikategorikan pada sisi masukulin dan feminin. Masyarakat menjadi belajar untuk menghormati manusia lainnya dengan segala pilihannya, selama hal tersebut bukanlah hal yang negatif.

\section{Simpulan}

Perubahan dalam masyarakat dapat mempengaruhi sistem sosial, sikap, nilai, dan pola perilaku individu. Setiap individu mengalami sebuah perubahan seiring dengan kemajuan zaman, baik dalam lingkungan keluarga maupun lingkungan sekitar. Perbedaan tersebut merupakan perubahan konsep sosial yang menekankan perubahan pada aspek kultural atau budaya dan aspek struktural masyarakat.

Dengan analisis wacana yang peneliti lakukan terhadap komentar-komentar pada akun Instagram beauty influencer laki-laki, peneliti menemukan jika masyarakat pada zaman dulu memiliki persepsi bahwa pria harus maskulin dan perempuan feminin. Sementara pada zaman sekarang, garis pembatasan gender semakin tipis dan lebih mengutamakan hak-hak manusia. Hal tersebut membuktikan bahwa persepsi mengenai identitas gender yang ada dalam masyarakat sudah perlahan-lahan berubah.

Munculnya konsep identitas gender yang berbeda saat ini sangat mempengaruhi pikiran masyarakat untuk dapat memahami perbedaan, tidak berarti bahwa perbedaan tersebut menjadikan seseorang salah. Masyarakat menjadi belajar untuk semakin menghormati manusia lainnya dengan segala pilihannya, selama hal tersebut tidak merugikan orang lain dan menjalani kegiatan yang positif.

\section{Ucapan Terima Kasih}

Dalam kesempatan ini, penulis ingin mengucapkan terima kasih kepada Tuhan Yang Maha Esa, orang tua, dosen pembimbing, teman-teman, serta orangorang terdekat penulis yang telah membimbing dan memberikan dukungan dalam berbagai hal sehingga membantu penulis menyelesaikan penelitian ini hingga akhir. Penulis juga mengucapkan terima kasih yang sebesar-besarnya kepada seluruh narasumber yang telah bersedia meluangkan waktu untuk diwawancarai sehingga memudahkan penulis dalam menyelesaikan penelitian ini.

\section{Daftar Pustaka}

Angeline, S., \& Rusdi, F. (2020). Maskulinitas yang Berubah: Analisis Wacana Konten Youtube Tysna Saputra.

Farida, H. (2016). Meneropong Gender Melalui Kacamata Genderles: Sebuah Pembacaan Butlerian Terhadap Ancillary Justice Karya (Vol. 1).

Puspitawati, H. (2013). Konsep, teori dan analisis gender. Bogor: Departemen Ilmu Keluarga dan Konsumen Fakultas Ekologi Manusia Institut Pertanian. 
Valent Novitaria, Farid Rusdi: Analisis Komentar Followers terhadap Identitas Gender Beauty Influencer Laki-Laki di Instagram

Rani, S., \& Udasmoro, W. (2015). Gender dan Identitas Dalam Sastra Di Mata Remaja, Masyarakat, Kebudayaan Dan Politik.

Yonatha, M., Ruyadi, Y., \& Anggraeni, L (2020). Alpha Makeup, Endi Feng, dan Jovi Adhiguna sebagai Tren Baru Konstruksi Gender Laki-Laki di Indonesia. 